\title{
Future climate and changes in flow patterns in Czech headwater catchments
}

\author{
A. Benčokováa ${ }^{1,2, *}$ P. Krám ${ }^{1}$, J. Hruška ${ }^{1,3}$ \\ ${ }^{1}$ Department of Environmental Geochemistry and Biogeochemistry, Czech Geological Survey, 11821 Prague 1, Czech Republic \\ ${ }^{2}$ Institute for Environmental Studies, Faculty of Science, Charles University in Prague, 12000 Prague 2, Czech Republic \\ ${ }^{3}$ Global Change Research Centre, Academy of Sciences of the Czech Republic, 60300 Brno, Czech Republic
}

\begin{abstract}
The aim of this study was to estimate the impacts of anticipated global climate change on runoff and evapotranspiration in small-forested catchments. The investigated Lysina and Pluhův Bor catchments are situated in the Slavkov Forest in western Czech Republic. To forecast hydrological patterns for the period 2071-2100, outputs from 2 general circulation models, HadAM3H and ECHAM4/OPYC3, were downscaled using 3 regional climate models (RCM; RCAO, CHRM, HIRHAM) under the A2 and B2 emission scenarios (Intergovernmental Panel on Climate Change Special Report on Emissions Scenarios). Corrected RCM daily outputs were used in combination with the hydrological model Brook90. Annual runoff is projected to decline by 10 to $30 \%$, and impacts on the distribution of monthly flow are projected to be significant, with summer-autumn decreases of 30 to $95 \%$, and winter increases of up to $40 \%$ compared to mean discharge for the period 1967-1990. Mean daily flows are estimated to decrease by $\sim 70 \%$ from August to November. These changes would have serious ecological consequences since streams could regularly dry up for short periods.
\end{abstract}

KEY WORDS: Climate change impact - Flow pattern - Regional climate scenarios $\cdot$ Headwater catchments $\cdot$ Hydrological modelling $\cdot$ Brook90

\section{INTRODUCTION}

Assessing the future climate and its potential effect on the hydrological cycle remains an important topic for research, since water availability affects both society and ecosystems (Prudhomme \& Davies 2008). Many recent regionally oriented projections have focused principally on changes in the future runoff of large European rivers (e.g. Jasper et al. 2004, Graham et al. 2007, Driessen et al. 2010, Hurkmans et al. 2010). In addition, some studies have focused on smaller catchments that are from tens to hundreds of square kilometres (Horton et al. 2006, Fowler \& Kilsby 2007, Horáyek et al. 2008). These studies were based on results from regional climate models (RCMs), and demonstrate a rising interest in the impact of expected climate change on hydrological patterns on a regional scale.
RCMs use lateral boundary conditions from general circulation models (GCMs) to produce higher resolution outputs. These RCMs encompass a scale of $\sim 0.5^{\circ}$ latitude and longitude, and parameterize physical atmospheric processes (Déqué et al. 2007). Newer runs at a scale of $0.22^{\circ}$ are also available (Hewitt \& Griggs 2004). In principle, RCMs are able to realistically simulate regional climate features such as orographic precipitation (e.g. Frei et al. 2003). However, it is difficult to represent all influences caused by geographical features in RCMs, especially for catchments with areas covering only a few square kilometres. Outputs still show systematic bias relating simulated temperature and precipitation to observed means (Christensen et al. 2008). To overcome this problem, the data need to either have higher spatial resolution, or an empirical correction is necessary for better representation of small catch- 
ments $\left(<10 \mathrm{~km}^{2}\right)$. Methods of bias correction have been developed in response to the latter requirement (e.g. Fowler \& Kilsby 2007, Terink et al. 2010).

This paper focuses on changes in hydrological patterns due to projected climate change at microscales, such as headwater catchments. The effective control of headwater catchments is an important factor in the sustainable development of water resources (Cutter \& Renwick 2003). In addition, headwater catchments, which in central Europe are often forested and located in mountainous regions, are areas of high ecological importance.

This study consists of 3 objectives: (1) evaluation of hydrological patterns in a reference period (19671990) by applying the hydrological model Brook90 (Federer et al. 2003), as calibrated to site specific conditions; (2) downscaling of climatic variables from 3 RCMs to micro-scale conditions; and (3) simulation of climate change impacts on future (2071-2100) hydrological patterns.

\section{MATERIALS AND METHODS}

\subsection{Site description}

The 2 experimental catchments in the western part of the Czech Republic are situated within a large spruce forest on the plateau of the Slavkov Forest (Slavkovský les) (Fig. 1). The Slavkov Forest is a protected mountainous region with an area of $610 \mathrm{~km}^{2}$ where many small streams with varying drainage areas originate. Both studied catchments belong to the Geochemical Monitoring (GEOMON) network of small forest catchments (Oulehle et al. 2008).

The first investigated catchment, Lysina (LYS; $50^{\circ} 03^{\prime} \mathrm{N}, 12^{\circ} 40^{\prime} \mathrm{E}_{\text {; }}$ area $0.273 \mathrm{~km}^{2}$ ) (Krám et al. 1997, Hruška \& Krám 2003), is located at 829 to $949 \mathrm{~m}$ above sea level (a.s.l.), and is facing NE with a mean slope of $11.5 \%$. Here, podzolized soils are developed on magnesium-poor granite. The vegetation is dominated by Norway spruce (Picea abies) that covers

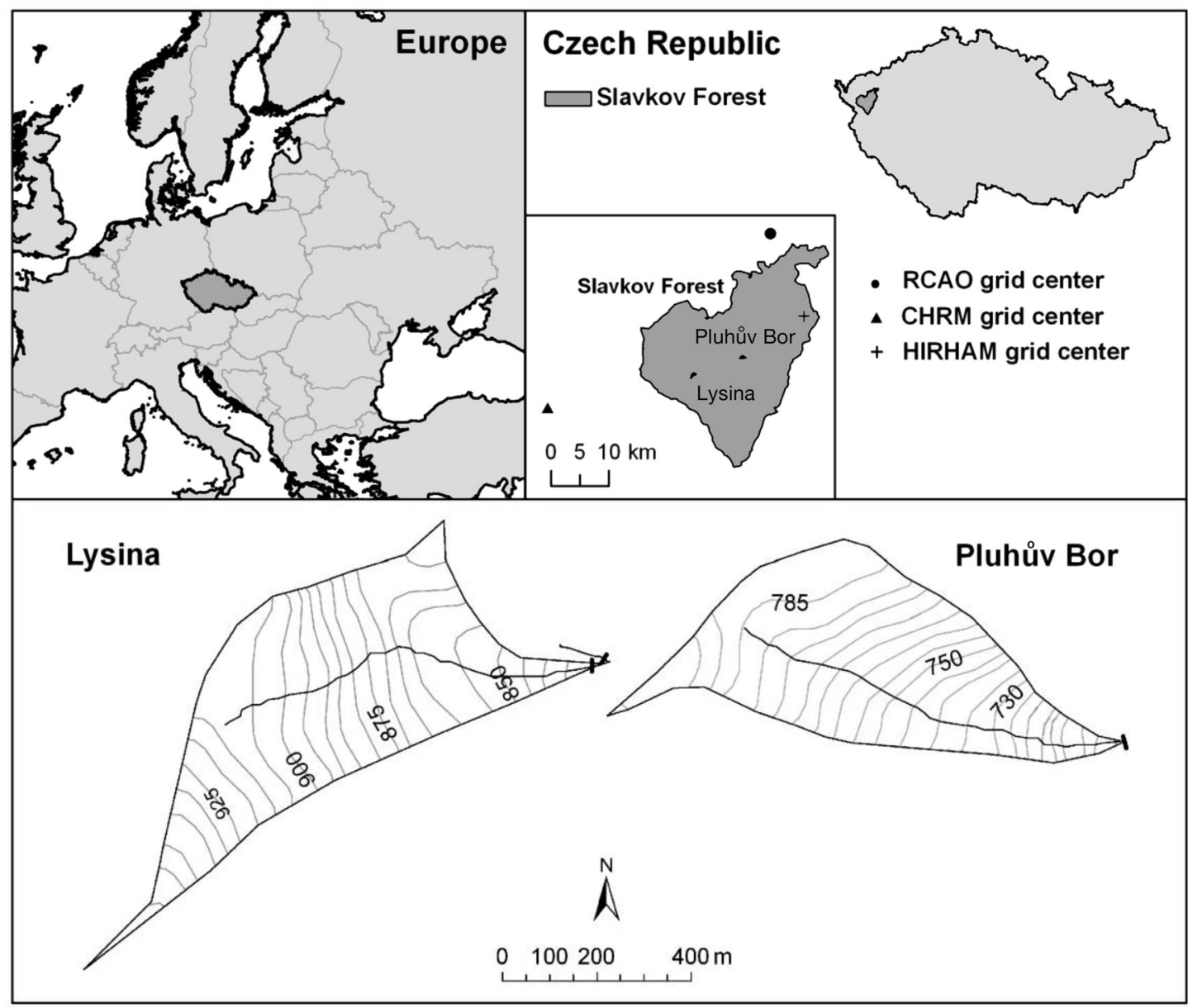

Fig. 1. Czech Republic, showing the location of the Slavkov Forest and the catchments of Lysina $\left(50^{\circ} 03^{\prime} \mathrm{N}, 12^{\circ} 40^{\prime} \mathrm{E}\right)$ and Pluhův Bor $\left(50^{\circ} 04^{\prime} \mathrm{N}, 12^{\circ} 46^{\prime} \mathrm{E}\right)$ 
almost $100 \%$ of the catchment. Recent average runoff was $450 \mathrm{~mm} \mathrm{yr}^{-1}$ (for the period 1990-2006).

The second study site, Pluhův Bor (PLB; $50^{\circ} 04^{\prime} \mathrm{N}$, $12^{\circ} 46^{\prime} \mathrm{E}_{\text {; }}$ area $0.216 \mathrm{~km}^{2}$ ) (Krám et al. 1997, Hruška \& Krám 2003), is a catchment with an elevation of 690 to $804 \mathrm{~m}$ a.s.l., and is facing SE with a mean slope of $13 \%$. Here, cambisols cover magnesium-rich serpentine rocks. The vegetation also consists of Norway spruce $(92 \%)$ mixed with Scots pine (Pinus sylvestris) (8\%). Recent average runoff was remarkably lower at $275 \mathrm{~mm} \mathrm{yr}^{-1}$ (1992-2006). Runoff was measured at both catchments using mechanical water-level recorders installed in combination with V-notch weirs.

Precipitation and temperature data are based on data from a meteorological station at Mariánské Lázně (700 m a.s.l.; 49 $59^{\prime} \mathrm{N}, 12^{\circ} 42^{\prime} \mathrm{E}$ ) located $\sim 5 \mathrm{~km}$ from LYS and $\sim 10 \mathrm{~km}$ from PLB. Average precipitation at the station was $844 \mathrm{~mm} \mathrm{yr}^{-1}$ and average air temperature was $6.2^{\circ} \mathrm{C}(1990-2006)$.

\subsection{The hydrological model Brook90}

The Brook90 model is a deterministic, processoriented, lumped parameter hydrological model that was designed to be applicable to any land surface at a daily time step year-round (Federer et al. 2003). Brook90 is a parameter-rich model designed primarily to study evapotranspiration and soil water movement at a point, with some provision for stream flow generation by different flow paths (Fig. 2). The major flow paths in the model are immediate infiltration to deeper layers by vertical pipes or macropipes, downslope drainage of some of the infiltrated 'new' water as 'bypass' flow in pipes (BYFL), surface drainage or overland flow, flow of noninfiltrated new water from variable saturated source areas, downslope matrix flow of 'old' water (DSFL), and vertical matrix drainage of old water to groundwater followed by groundwater discharge (VRFL). Snow accumulation and melt are controlled by a degree-day method with cold content (Linsley 1949). The model uses the Shuttleworth \& Wallace (1985) method for separating tran- spiration from soil evaporation, and evaporation of interception.

Daily precipitation, maximum and minimum air temperatures, daily solar radiation and daily mean wind speeds were used as inputs to the Brook90 model. Five further parameter sets were required: canopy, location, soil (for up to 25 layers), initial, and fixed parameters.

\subsection{Input data}

Meteorological data for the studied catchments (minimum and maximum daily air temperature, daily precipitation, daily mean wind speed and sunshine duration) for the period 1967-2006 were taken from a climate station of the Czech Hydrometeorological Institute located at Mariánské Lázně. Air temperature data were corrected based on local minimum and maximum temperature lapse rates to represent the average catchment altitudes. The lapse rates for individual months were calculated by linear regression using data from 5 climate stations (within a radius of $100 \mathrm{~km}$ ) ranging in elevation from 519 to $1118 \mathrm{~m}$. The decrease varied between 0.1 to $0.3^{\circ} \mathrm{C} 100 \mathrm{~m}^{-1}$ for the minimum temperature and 0.3 to $0.7^{\circ} \mathrm{C}$ for the maximum temperature. Daily precipitation data were corrected by a factor

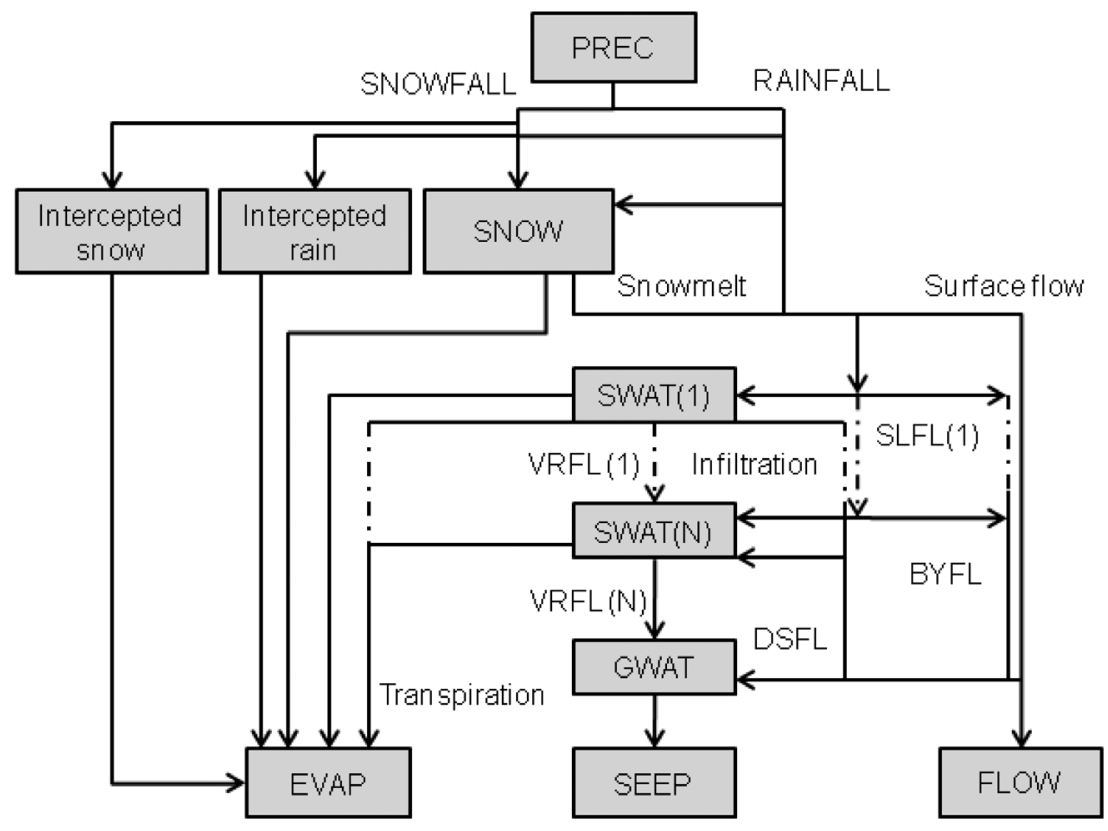

Fig. 2. Major Brook90 processes. BYFL: bypass flow rate from all layers, DSFL: downslope flow rate from all layers, EVAP: evapotranspiration, GWAT: groundwater storage below soil layers, PREC: precipitation, SEEP: deep seepage, SLFL: input rate to soil surface, SWAT(1-N): soil water in layers, VRFL(1-N): vertical matrix drainage rate from layer. Dot-dash lines: layers between 1 and N. Modified from Federer (2002) 
calculated from the difference between average annual precipitation measured by bulk collectors at the investigated catchments and annual precipitation from the Mariánské Lázně station (for 19942006). The daily precipitation data for Lysina were therefore increased by $14 \%$, while those from Mariánské Lázně were used unchanged for Pluhův Bor because the difference was negligible $(1 \%)$. Daily global radiation was calculated from the sunshine duration using the Klabzuba approach (described in Trnka et al. 2005). The daily wind speed data from the Mariánské Lázně station were used unchanged (Fig. 3). The daily average vapour pressure data were estimated by the Brook90 model using saturated vapour pressure at minimum temperature, while canopy and some of the site specific (location) parameters (including the parameter range) were taken from Federer (2002) and Federer et al. (2003). Soil parameters were set for 3 layers according to the soil profile (Krám et al. 1997), and Clapp \& Hornberger (1978) values for different soil texture classes. Initial and fixed parameter sets for Brook90 were taken from Federer (2002).

\subsection{Calibration and validation of the hydrological model}

The calibration of Brook90 and validation of model performance were based on daily discharge data from the catchment outlets. Seventeen years of observation (1990-2006) were used to set Brook90 for the Lysina catchment. Data from the period 19901999 were used for calibration, and the interval 2000-2006 was considered as the validation period. The same approach was applied at Pluhův Bor except for the use of a shorter period for validation: 19922001 for calibration and 2002-2006 for validation.

Selected canopy and location parameter values (Table 1) were estimated using parameter estimation software (PEST; Doherty 2003, 2004). The success of model calibration was evaluated by testing the significance of the correlation between simulated and measured daily and monthly stream flow (Pearson's correlation coefficient r) and the Nash-Sutcliffe criterion on monthly flow (Nash \& Sutcliffe 1970).

A local sensitivity analysis (does not account for possible interactions among the parameters) using

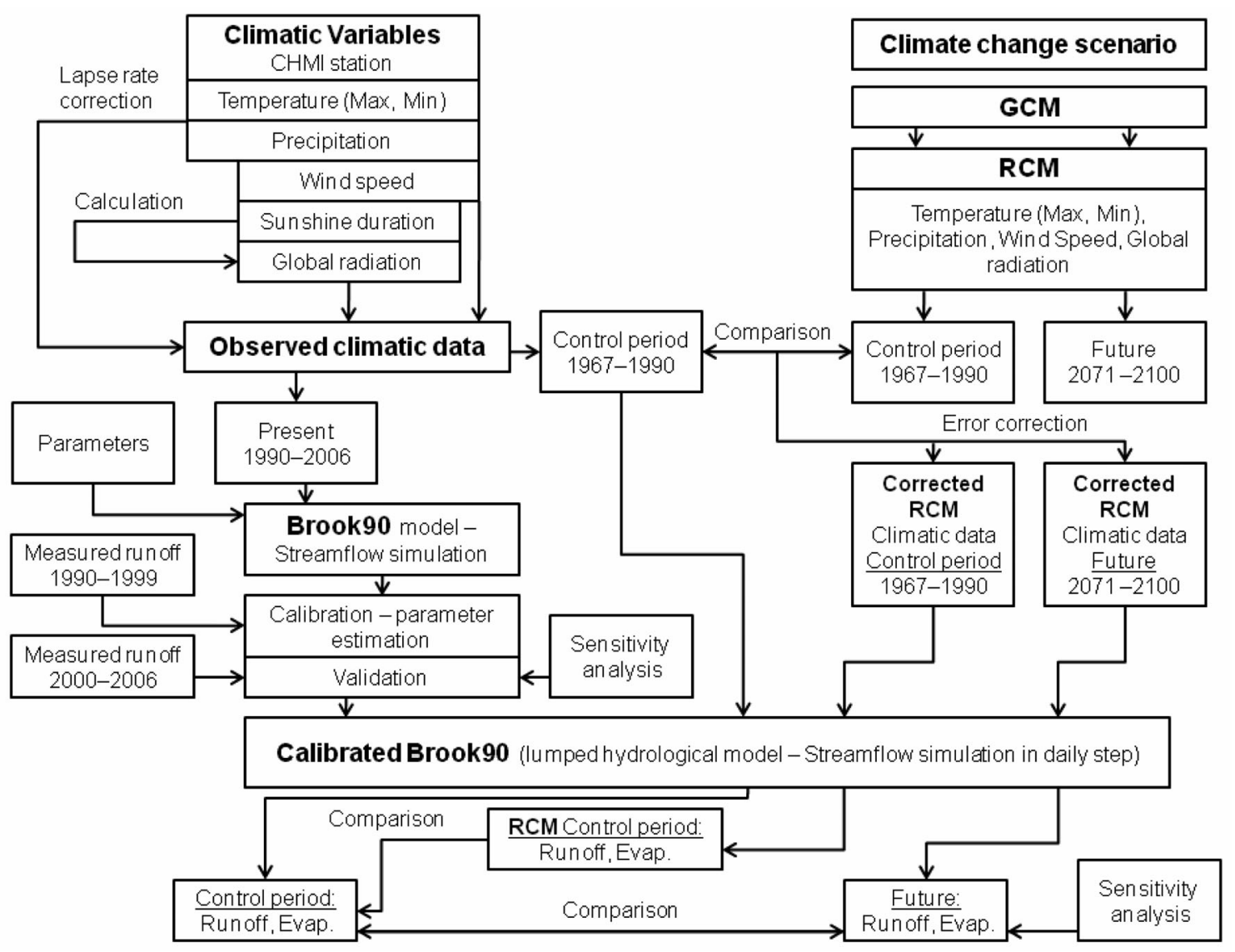

Fig. 3. Scheme of the modelling design. CHMI: Czech Hydrometeorological Institute, GCM: general circulation model, RCM: regional climate model 
Table 1. Canopy and location parameters tested for sensitivity and model calibration for the Lysina (LYS) and Pluhův Bor (PLB) catchments. ALB: albedo; ALBSN: surface reflectivity with and without snow on the ground; MAXLAI: maximum leaf area index for the year; KSNVP: multiplier to reduce snow evaporation; MELFAC: degree-day melt factor for open land ( $\left.\mathrm{MJ} \mathrm{m}^{-2} \mathrm{~d}^{-1} \mathrm{~K}^{-1}\right)$; MAXHT: maximum canopy height for the year $(\mathrm{m})$; MXRTLN: maximum length of fine roots per unit ground area $\left(\mathrm{m} \mathrm{m}^{-2}\right)$; MXKPL: maximum plant conductivity $\left(\mathrm{mm} \mathrm{d}^{-1} \mathrm{MPa}^{-1}\right)$; GLMAX: maximum leaf conductance $\left(\mathrm{cm} \mathrm{s}^{-1}\right)$; CI: confidence intervals

\begin{tabular}{|c|c|c|c|c|c|c|}
\hline \multirow[b]{2}{*}{ Parameters } & \multicolumn{2}{|c|}{- LYS $_{;} \mathrm{PLB}-$} & \multicolumn{2}{|c|}{- LYS -} & \multicolumn{2}{|c|}{$\longrightarrow$ PLB } \\
\hline & $\begin{array}{l}\text { Initial } \\
\text { value }\end{array}$ & Range & $\begin{array}{l}\text { Final } \\
\text { value }\end{array}$ & $\begin{array}{c}95 \% \\
\text { CI }\end{array}$ & $\begin{array}{l}\text { Final } \\
\text { value }\end{array}$ & $\begin{array}{c}95 \% \\
\text { CI }\end{array}$ \\
\hline ALB & 0.07 & $0.07-0.15$ & 0.07 & $0.06-0.08$ & 0.15 & $0.13-0.16$ \\
\hline ALBSN & 0.3 & $0.1-0.9$ & 0.44 & $0.40-0.48$ & 0.18 & $0.13-0.23$ \\
\hline MAXLAI & 7 & $4-10$ & 7.45 & $7.12-7.78$ & 7.90 & $7.48-8.31$ \\
\hline KSNVP & 0.3 & $0.01-1$ & 0.46 & $0.40-0.52$ & 0.21 & $0.14-0.28$ \\
\hline MELFAC & $1.5 ; 1.9$ & $0.5-2$ & 1.41 & $1.34-1.48$ & 2.00 & $1.93-2.07$ \\
\hline MAXHT & 25 & $15-30$ & 26.15 & $25.59-26.72$ & 24.49 & $23.91-25.07$ \\
\hline MXRTLN & 2100 & $1000-3500$ & 2719 & $2468-2969$ & 2073 & $1756-2390$ \\
\hline MXKPL & 8 & $5-15$ & 8.91 & $8.34-9.47$ & 7.76 & $7.37-8.16$ \\
\hline GLMAX & 0.53 & $0.2-2$ & 0.78 & $0.74-0.83$ & 0.72 & $0.68-0.76$ \\
\hline
\end{tabular}

(Vidale et al. 2003; hereafter CHRM-H) with the A2 emission scenario, and HIRHAM (Hanssen-Bauer et al. 2003; hereafter HIRH-H) with the A2 and B2 emission scenarios.

These future climate scenarios are based on the IPCC A2 and B2 SRES (Special Report on Emissions Scenarios) anthropogenic $\mathrm{CO}_{2}$ emissions scenarios (Nakićenović et al. 2000). Simulated daily maximum and minimum temperatures, daily amounts of precipitation, global radiation, and average daily wind speed were downloaded from the PRUDENCE project (Prediction of Regional scenarios and Uncertainties for

PEST was applied to identify sensitive parameters. This programme is primarily used to estimate an optimal parameter set. The objective function is based on the least-squares criterion. The optimization problem is iteratively solved by linearization of the relationship between a model's output and its parameters, using the Gauss-Marquardt-Levenberg algorithm (Marquardt 1963, Levenberg 1944).

The PEST results (Table 1) were further combined with the nominal range method to calculate the percentage change in outputs due to the changes in model inputs (relative to their baseline values). The aim was to identify the changes in individual months, since the effects of some parameters are seasonally determined. Further, the effect of the parameter changes on runoff in the measured data period was compared with the projected effect.

\subsection{Regional climate model data}

Three RCMs with 2 driving GCMs and 2 emission scenarios were used. The regional climate model RCAO (Räisänen et al. 2003) was used with lateral boundary conditions from 2 GCMs: Had AM3H (Hadley Centre, UK, hereafter RCAO-H) and ECHAM4/OPYC3 (European Centre Hamburg Model, developed at the Max Planck Institute for Meteorology, Germany, hereafter RCAO-E), each run with A2 and B2 emission scenarios. Two further models were utilized using HadAM3H boundary conditions: the limited area model CHRM
Defining EuropeaN Climate change risks and Effects; http://prudence.dmi.dk). The PRUDENCE results have been further developed and enhanced through the ENSEMBLES project (Ensemble-based Predictions of Climate Changes and their Impacts; http://ensembles-eu.metoffice.com/).

These datasets are available for $0.44^{\circ}$ grids $(\sim 50 \mathrm{~km}$ resolution) for a control period from 1961-1990 and a scenario period from 2071-2100. Simulated climatic data were used for the grids covering the area of the Slavkov Forest (Fig. 1). This included: the RCAO grid centered at $50^{\circ} 15^{\prime} 25^{\prime \prime} \mathrm{N}, 12^{\circ} 50^{\prime} 18^{\prime \prime} \mathrm{E}$ with an average elevation of $579 \mathrm{~m}$ a.s.l.; the CHRM grid centered at $49^{\circ} 58^{\prime} 28^{\prime \prime} \mathrm{N}, 12^{\circ} 18^{\prime} 46^{\prime \prime} \mathrm{E}$ with an average elevation of $578 \mathrm{~m}$ a.s.l.; and the HIRHAM grid centered at $50^{\circ} 7^{\prime} 43^{\prime \prime} \mathrm{N}, 12^{\circ} 55^{\prime} 39^{\prime \prime} \mathrm{E}$ with an average elevation of $565 \mathrm{~m}$ a.s.l.

Simulated RCM climatic data for the control period (1967-1990) markedly differed from measured data (Fig. 4), and were therefore transformed for hydrological modelling purposes. One of the possible ways to correct the modelled climate variables is to apply factors based on the ratio of the control climatology to observed values on a grid point basis (as Durman et al. 2001). A simple monthly bias correction approach was used (e.g. Fowler \& Kilsby 2007). Correction factors were calculated as the difference or the ratio between the monthly means of measured and simulated climatic data in the control period. Daily input data series were corrected by these monthly factors so that the modelled monthly average in the control climate matched the observed monthly average over the 

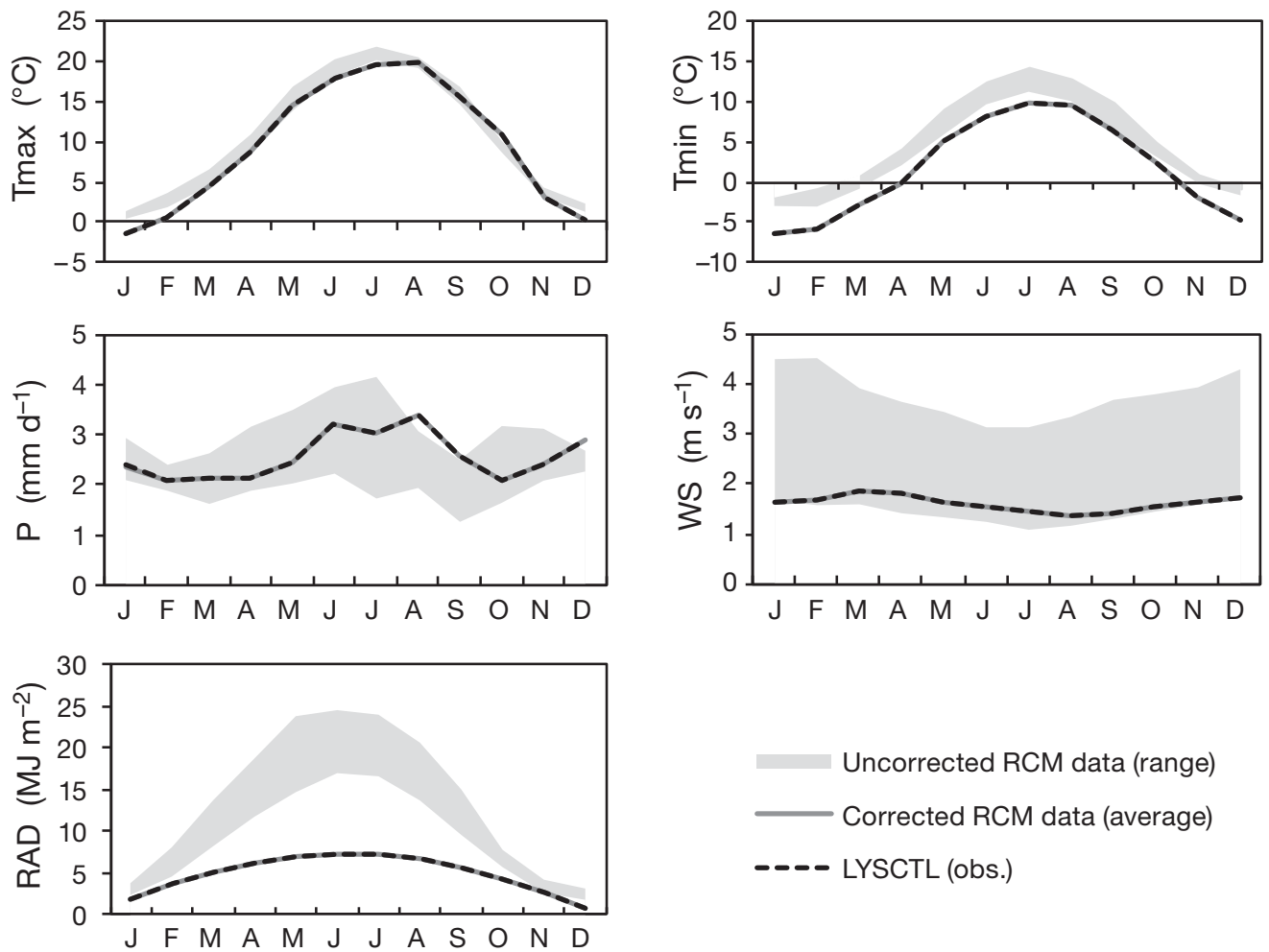

Fig. 4. Effect of data correction. Comparison of observed climatic data with uncorrected and corrected RCM data for Lysina in the control period (LYSCTL; 1967-1990). The range was based on the difference between the mean maximum and minimum scenarios for Tmax and Tmin. Tmax: maximum daily temperature, Tmin: minimum daily temperature, P: precipitation, WS: mean daily wind speed, RAD: daily global radiation

period 1967-1990. The projected future data were adjusted by the same factors as for the control climate. For an assessment of the future projection uncertainty, a CI of the scenario mean was used. The CI was calculated using the nonparametric bootstrap approach (Crawley 2002). The data were resampled $(10000 \times$ in our case) and the values that characterise the tails of the distribution, the 97.5 and 2.5 percentiles, were calculated.

The average monthly difference between the simulations with the observed and the RCM data in the control period was given by:

$$
\mathrm{MBE}=\sum_{i=1}^{N} \frac{\left(\mathrm{R}_{\mathrm{RCM}, i}-\mathrm{R}_{\mathrm{obs}, i}\right)}{N}
$$

where MBE is the mean bias error, $N$ is the number of RCM time series used for simulation, $\mathrm{R}_{\mathrm{RCM}, i}$ is the mean monthly runoff simulated with RCM bias corrected data, and $R_{\mathrm{obs}, i}$ is the mean monthly runoff simulated with observed data. The magnitude of the error in RCM simulation in the control period was given by the root mean square error RMSE:

$$
\operatorname{RMSE}=\sum_{i=1}^{N} \sqrt{\frac{\left(\mathrm{R}_{\mathrm{RCM}, i}-\mathrm{R}_{\mathrm{obs}, i}\right)^{2}}{N}}
$$

\subsection{Trends in recent data}

For testing recent changes in measured monthly precipitation, air temperature and simulated runoff (1967-2006), the nonparametric Yue-Pilon method was applied (Yue et. al. 2002a). This removes serial correlation components such as the lag-one autoregressive (AR (1)) process from the time series. The magnitude of the trend is computed by the Yue-Pilon method using the Theil-Sen approach. If the slope differs from zero, then it is assumed to be linear and the data is detrended by the slope; the AR (1) is then computed for the detrended series. The residuals should be an independent series. The trend and residuals are then blended together. The MannKendall test (Yue et al. 2002b) is then applied to the blended series to assess the trend significance.

\section{RESULTS}

\subsection{Performance of the models}

The corrected RCM data were used for runoff modelling using the calibrated Brook90 model in the con- 

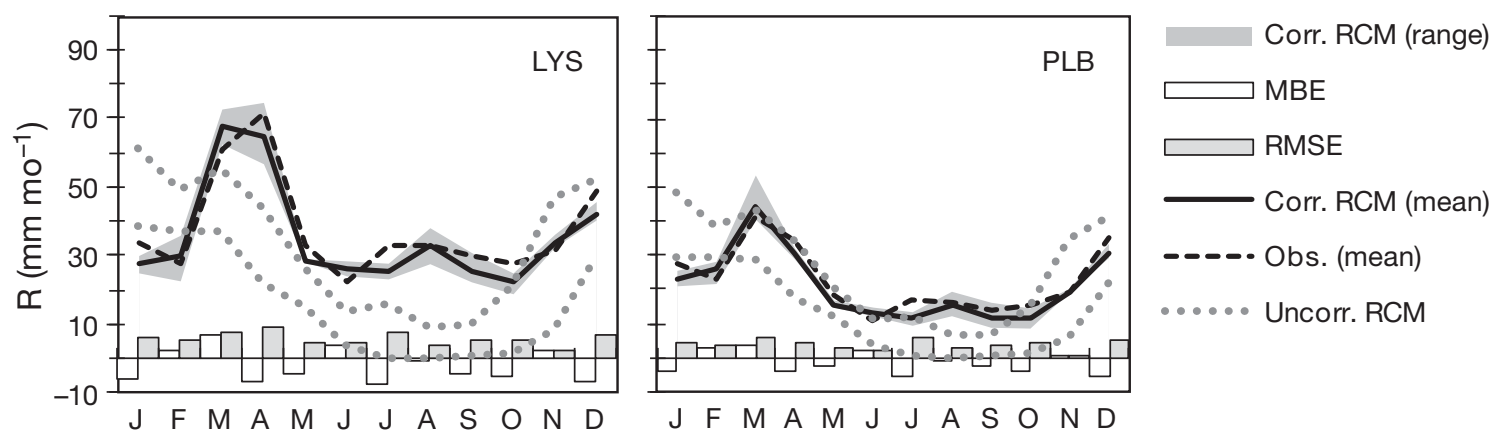

Fig. 5. Monthly mean runoff (R) modelled by Brook90 using observed data and RCM simulated data (corrected and uncorrected) at Lysina (LYS) and Pluhův Bor (PLB) in the control period (1967-1990). Range of corrected RCMs based on difference between mean maximum and minimum scenarios for Tmax and Tmin. MBE and RMSE: mean bias error and root mean square error, respectively, for the runoff simulation, with bias corrected RCM data

trol period (1967-1990). The seasonal runoff distribution based on RCM data showed similar patterns as the runoffs simulated with observed climatic data from Mariánské Lázně (Fig. 5). The mean annual runoff from the Lysina catchment was $453 \mathrm{~mm}$ in the control period. The mean annual runoffs calculated from the RCM corrected climatic data ranged between 407 and $442 \mathrm{~mm}$. The mean annual runoff from the Pluhův Bor catchment was $272 \mathrm{~mm}$ as simulated with observed climatic data, and 239 to $266 \mathrm{~mm}$ as calculated from RCM corrected data. However, the runoff simulated with RCM corrected data was usually lower by $<10 \%$ on average. The MBE and RMSE did not markedly differ and varied between $\sim 1$ to $10 \mathrm{~mm} \mathrm{mo}^{-1}$ (Fig. 5). Runoff simulated with RCM corrected and uncorrected data differed markedly, with a clear shift in seasonality (Fig. 5). In addition, the summer runoff calculations simulated with uncorrected RCM data were much lower, especially for the Lysina catchment. This was a result of the overestimation of evapotranspiration caused by much higher global radiation and daily mean wind speed compared to observed data.

In general, Brook90 well reproduced the discharge conditions in the investigated catchments, including both individual flood events and long-term runoff. The Nash-Sutcliffe $\mathrm{R}^{2}$ for monthly data from 19902006 demonstrated high model performance for both study sites, with $\mathrm{R}^{2}$ values mostly ranging from 0.6 to 0.9 . For the validation period (2000-2006) at the Lysina catchment, the Pearson's correlation coefficient was $0.91\left(\mathrm{r}_{\text {crit }}=0.22, \mathrm{n}=84, \mathrm{p}=0.05\right)$ for monthly data and $0.73\left(\mathrm{r}_{\text {crit }}=0.20, \mathrm{n}=2557, \mathrm{p}=0.05\right)$ for daily data. For Pluhův Bor, the correlation coefficient was $0.82\left(\mathrm{r}_{\text {crit }}=0.25, \mathrm{n}=60, \mathrm{p}=0.05\right)$ for monthly data and $0.73\left(\mathrm{r}_{\text {crit }}=0.20, \mathrm{n}=1826, \mathrm{p}=0.05\right)$ for daily data during the same period.

The results of sensitivity analysis showed that Brook90 is sensitive to canopy and location parame- ters affecting evapotranspiration. The most sensitive parameters were maximum leaf conductance and maximum leaf area index (MAXLAI). Changing these within the parameter range led to an increase in annual runoff of up to $17 \%$ (using values close to the lower bound of the parameter range) or a decrease of up to $30 \%$ (with parameters close to the upper bound). Relatively sensitive parameters were maximum canopy height, length of fine roots per unit ground area and maximum plant conductivity.

In general, future runoff will be more sensitive to parameter values reducing evapotranspiration (resulting in an increase in runoff). This was notable especially in spring and autumn, when the model was highly sensitive to a change in MAXLAI. The change in MAXLAI in March and April resulted in $<5 \%$ difference in evapotranspiration in the present period, but a 10 to $30 \%$ difference in the future. The sensitivity to MAXLAI in November was -30 to $10 \%$ for the present period but -50 to $300 \%$ in the future (compared to the run with selected parameters in Table 1 and corrected future RCM input data). This might be a result of a future shift in the growing season.

\subsection{Recent changes in air temperature, precipita- tion and runoff}

Annual temperature means for the Slavkov Forest from $1990-2006$ were $0.5^{\circ} \mathrm{C}$ higher than those from the control period (1967-1990), resulting in a mean annual temperature increase from 4.5 to $5.0^{\circ} \mathrm{C}$ at the Lysina catchment and from 5.2 to $5.7^{\circ} \mathrm{C}$ at Pluhův Bor. However, the overall trend in annual temperature increase from 1967-2006 was not significant. The only significant changes were in the maximum monthly temperatures in April and May $(\mathrm{p}<0.05$, 
$+2.3^{\circ} \mathrm{C}$ for the period $1967-2006$ ). The mean annual amount of precipitation did not change significantly from the control period $\left(937 \mathrm{~mm} \mathrm{yr}^{-1}\right)$ to the present (961 mm yr ${ }^{-1}$ for $\left.1990-2006\right)$ at Lysina or at Pluhův Bor (from 822 to $861 \mathrm{~mm} \mathrm{yr}^{-1}$ for the control period and the present, respectively). However, a significant trend was found in February precipitation, with an increase of $30 \mathrm{~mm}(\mathrm{p}<0.05)$ for the period 1967-2006.

The mean annual runoff (simulated with measured input data) did not change significantly from the control period (1967-1990) to the 1990-2006 period at both Lysina (from 453 to $450 \mathrm{~mm} \mathrm{yr}^{-1}$ ) and Pluhův Bor (from 272 to $275 \mathrm{~mm} \mathrm{yr}^{-1}$ ). Significant seasonal distribution trends were found for runoff in February and November. At both catchments, monthly runoff means for 1967-2006 increased ( $\mathrm{p}<0.05)$ in February by 22 and $18 \mathrm{~mm}$ at Lysina and Pluhův Bor, respectively), and decreased $(\mathrm{p}<0.05)$ in November by 25 and $13 \mathrm{~mm}$ at Lysina and Pluhův Bor, respectively). Maximum monthly runoff shifted from April to March at Lysina, but remained in March at Pluhův Bor, between the periods 1967-1990 and 1990-2006.

\subsection{Projected future changes in air temperature and precipitation}

The RCM models estimated an increase in mean annual $2 \mathrm{~m}$ air temperatures of between 2.5 and $5.8^{\circ} \mathrm{C}$ for the Slavkov Forest (2071-2100 compared to the control period 1967-1990). This represents an increase in mean annual $2 \mathrm{~m}$ temperatures to 7.0 to $10.3^{\circ} \mathrm{C}$ at Lysina and 7.7 to $11.0^{\circ} \mathrm{C}$ at Pluhův Bor.

An increase in $2 \mathrm{~m}$ maximum and minimum temperatures for all months throughout the year was projected for 2071-2100 (Fig. 6), with the largest changes occurring in August maxima. However, a noticeable increase in temperature was also predicted for the winter months, especially in minimum temperature. Increased temperatures in November would shift the average daily minimum temperatures above the freezing point, to 0.3 to $3.1^{\circ} \mathrm{C}$ in Lysina and 0.6 to $3.5^{\circ} \mathrm{C}$ in Pluhův Bor. The CIs of scenario means ranged within \pm 0.2 to $0.5^{\circ} \mathrm{C}$ (Fig. 6). In addition, the RCAO-E based projections also showed a rise in mean minimum daily temperatures above the freezing point in other months: in March at both catchments, and in February at Pluhův Bor. These increases in winter minimum temperatures above the freezing point would be reflected in changes to the snow cover period. The past average snow cover period (1967-1990) lasted from the end of November to the middle of April at Lysina, and from the beginning of December to the end of March at Pluhüv Bor. These periods would be significantly shorter in the future: from the second half of December to the beginning of March at Lysina, and from the second half of December to the second half of February at Pluhův Bor. Similarly, the mean durations of snow cover were also projected to decrease, from $\sim 130$ to $\sim 40-110$ d at Lysina (control period versus 20712100 ), and from $\sim 120$ to $\sim 20-80$ d at Pluhův Bor.
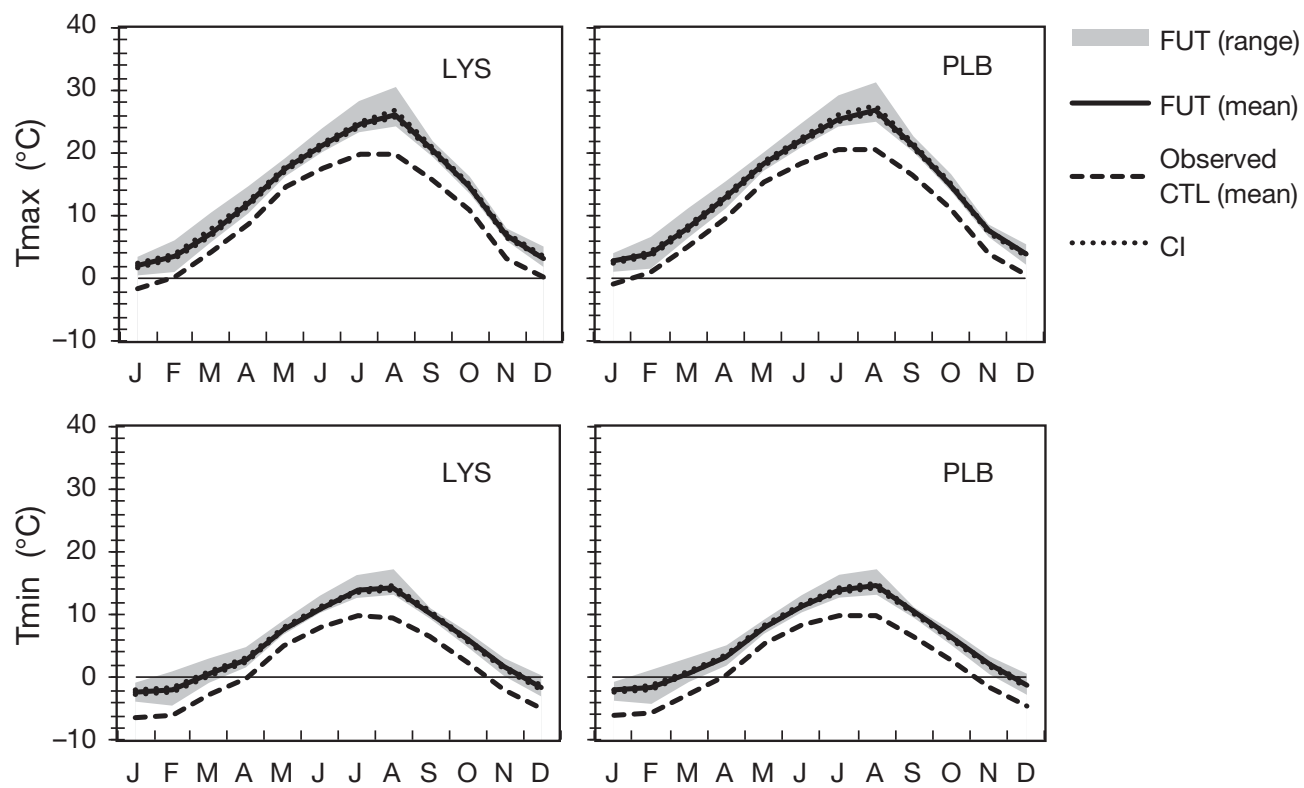

Fig. 6. Mean annual cycle of $2 \mathrm{~m}$ maximum and minimum air temperature for Lysina and Pluhův Bor. FUT: future scenario period (2071-2100), CTL: control period (1967-1990). Range based on difference between mean maximum and minimum scenarios for Tmax and Tmin. CI: confidence interval for the mean of all RCM simulations 
Table 2. Water balance parameters (all in $\mathrm{mm} \mathrm{yr}^{-1}$ ) at the investigated catchments in the control period (1967-1990), present (1990-2006 LYS, 1992-2006 PLB), and future (20712100). Future projections were based on downscaling of regional climate models with 2 driving global circulation models and 2 emission scenarios (see Section 2.5 for details). Evapotranspiration as well as control and future runoff data were simulated using Brook90

\begin{tabular}{|c|c|c|c|}
\hline & Precipitation & Evapotransp. & Runoff \\
\hline \multicolumn{4}{|l|}{ Lysina } \\
\hline Control & $937^{\mathrm{a}}$ & 390 & 453 \\
\hline Present & $961^{\mathrm{a}}$ & 398 & $450^{c}$ \\
\hline \multicolumn{4}{|l|}{ Future } \\
\hline RCAO-H/A2 & $954^{\mathrm{b}}$ & 467 & 402 \\
\hline RCAO-H/B2 & $924^{\mathrm{b}}$ & 455 & 387 \\
\hline RCAO-E/A2 & $879^{\mathrm{b}}$ & 493 & 320 \\
\hline RCAO-E/B2 & $957^{\mathrm{b}}$ & 493 & 385 \\
\hline CHRM-H/A2 & $929^{b}$ & 457 & 391 \\
\hline HIRH-H/A2 & $890^{\mathrm{b}}$ & 457 & 359 \\
\hline HIRH-H/B2 & $928^{\mathrm{b}}$ & 452 & 392 \\
\hline \multicolumn{4}{|l|}{ Pluhův Bor } \\
\hline Control & $822^{\mathrm{a}}$ & 403 & 272 \\
\hline Present & $861^{\mathrm{a}}$ & 415 & $275^{c}$ \\
\hline \multicolumn{4}{|l|}{ Future } \\
\hline RCAO-H/A2 & $837^{b}$ & 470 & 237 \\
\hline RCAO-H/B2 & $810^{\mathrm{b}}$ & 457 & 229 \\
\hline RCAO-E/A2 & $771^{\mathrm{b}}$ & 481 & 188 \\
\hline RCAO-E/B2 & $840^{\mathrm{b}}$ & 493 & 225 \\
\hline CHRM-H/A2 & $814^{\mathrm{b}}$ & 462 & 230 \\
\hline HIRH-H/A2 & $781^{\mathrm{b}}$ & 458 & 210 \\
\hline HIRH-H/B2 & $814^{\mathrm{b}}$ & 453 & 233 \\
\hline \multicolumn{4}{|c|}{ 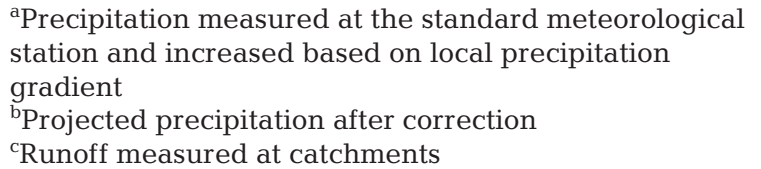 } \\
\hline
\end{tabular}

According to these RCAO-E A2 and B2 scenarios, the shorter overall snow cover periods would not be continuous but would be interrupted by complete melting.

Minor differences in the annual amount of precipitation (1 to $6 \%$ ) were expected for the future (Table
2). However, significant changes were projected in the annual distribution of precipitation (Fig. 7) The magnitude of these changes differed from month to month, but models with the A2 and B2 scenarios showed a similar pattern: a drop in precipitation from July to September and an increase from December to March. The maximum projected decrease was in August (17 to $43 \%$ ). The highest increase was projected to be in December (up to $51 \%$ ). The CIs of scenario means ranged within $\pm 3-7 \mathrm{~mm}$ (Fig. 7).

\subsection{Future changes in evapotranspiration and runoff}

The increase in annual evapotranspiration based on model projections was estimated to be $\sim 15$ to $25 \%$ at the Lysina and $\sim 10$ to $20 \%$ at the Pluhův Bor catchment (Table 2). Changes in the seasonal distribution showed an increase for almost all months (Fig. 8). The highest absolute increases were from May to July. In general, changes in August and September were expected to be only minor. One exception was the decrease by $\sim 20 \%$ in August at Pluhův Bor according to the RCAO-E/A2 scenario. This decrease could be a result of actual evapotranspiration being limited by water availability. The CIs of the scenario means ranged within $\pm 2 \mathrm{~mm}$ (Fig. 8). Monthly evapotranspiration means for the control and scenario periods are listed in Appendices 1 \& 2 .

Annual runoff was projected to decrease by $\sim 10$ to $30 \%$ (LYS) and $\sim 15$ to $30 \%$ (PLB) (Table 2). This decrease was expected from April to November (up to $90 \%$ ), with a maximum absolute decline in April (Fig. 9). The RCAO-H, CHRM-H, and HIRH-H projections showed the mean monthly maximum in March, while the RCAO-E projections showed the maximum in December. Runoff from December to February was mainly projected to rise, with the maximum change in February. The difference between
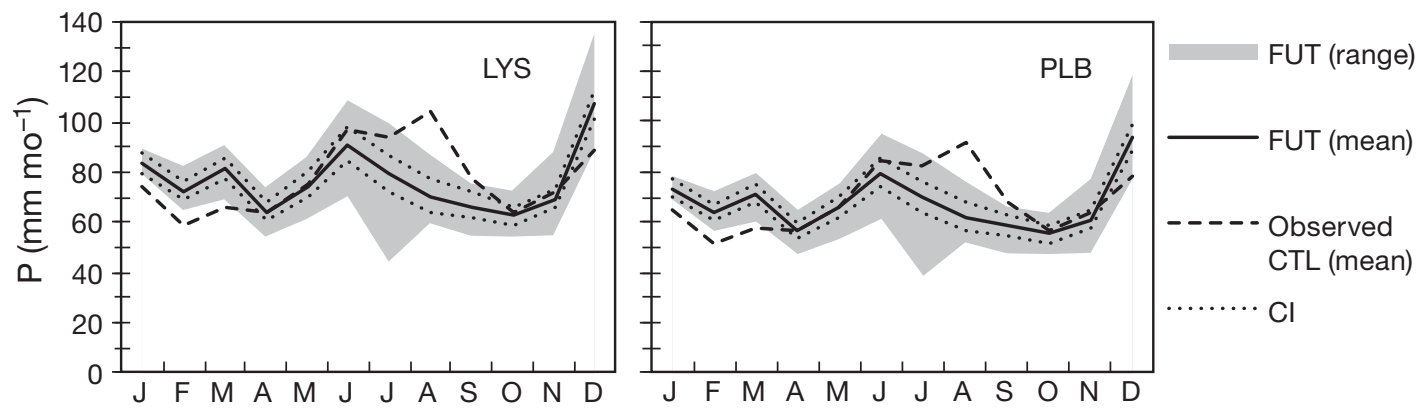

Fig. 7. Annual series of mean precipitation (P) for Lysina (LYS) and Pluhův Bor (PLB). FUT: future scenario period (2071-2100), CTL: control period (1967-1990). Range was based on difference between mean maximum and minimum scenarios for precipitation. CI: confidence interval for the mean of all RCM simulations 

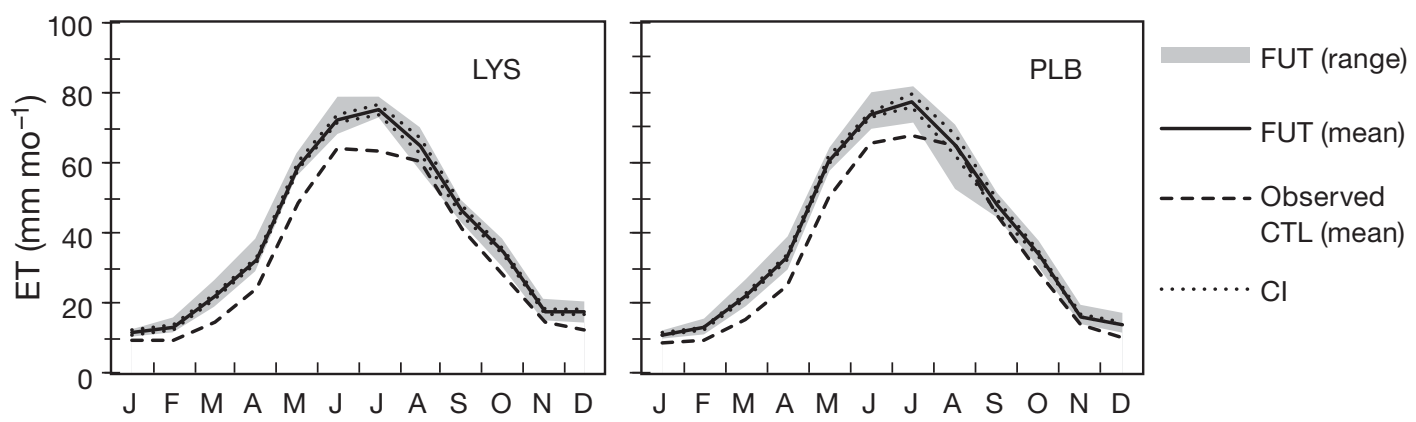

Fig. 8. Annual series of mean evapotranspiration (ET) for Lysina (LYS) and Pluhův Bor (PLB); FUT: future scenario period (20712100); CTL: control period (1967-1990). Range based on difference between mean maximum and minimum scenarios for evapotranspiration. CI: confidence interval for the mean of all RCM simulations

future summer mean and median of the projections indicates that the mean values were shifted up by the high flows (Fig. 9). A comparison of the inter-quartile range ( 25 to $75 \%$ ) and the mean value (Fig. 9) shows that in August for both sites and in July and September for PLB, the third quartile of monthly runoffs would be lower than the expected mean of all projections. The driest month would be September. The first quartile for LYS and even the second for PLB
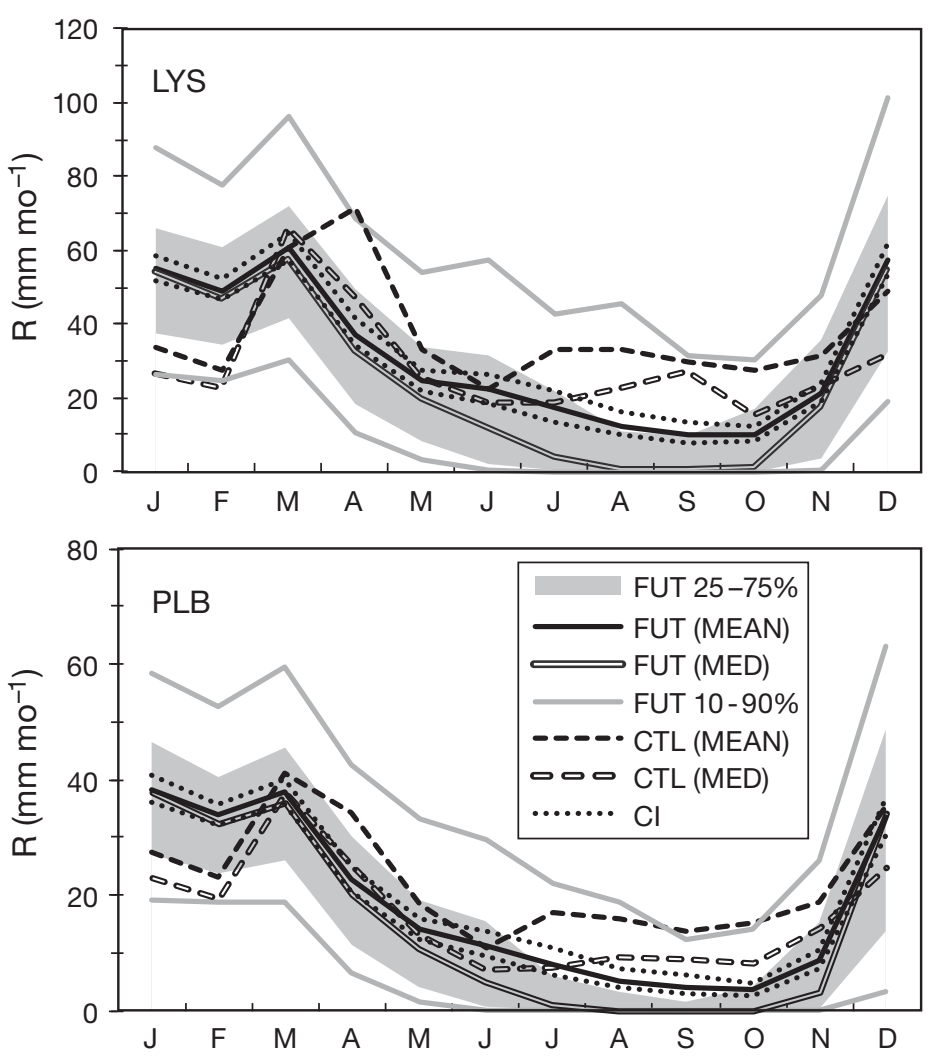

Fig. 9. Annual series of mean runoff (R) for Lysina (LYS) and Pluhův Bor (PLB). FUT: future scenario period (2071-2100); CTL: control period (1967-1990). 25-75\%: inter-quartile range of all scenarios. 10-90\%: inter-quintile range. CI: confidence interval for the mean of all RCM simulations reached the value of zero for monthly runoffs for this month. It means that there is a $25 \%$ (LYS) or $50 \%$ (PLB) probability that the stream would completely dry out during September. This indicates that the future flow pattern would likely be shifted to more extremes. Dry periods would be followed by relatively high flows. The monthly runoff means for the control and scenario periods are listed in Appendices $3 \& 4$. The fact that precipitation exceeded the sum of evapotranspiration and runoff (Table 2) is a result of deep seepage (according to the Brook90 model).

The cumulative frequency distribution of mean daily runoff showed significant changes between the control period and future runoff (Fig. 10). Simulations indicated that both streams could dry up completely for short periods, especially during September and October (based on the RCAO-E scenario). The mean daily flow from August-October could decline by $~ 60 \%$ (LYS) and $70 \%$ (PLB).

\section{DISCUSSION}

The discrepancy between observed and RCM simulated data (Fig. 4) emphasises the need for correction of all input data series. The differences in temperatures and precipitation can partially be explained by the discrepancy between RCM grids and catchment elevation. However, it is mainly a result of an error in the RCM data simulation since the outputs are not resolved enough to include influences of all topographical features (Christensen et al. 2008). The standard deviations in RCM temperature and precipitation data in mid-Europe was estimated by Déqué et al. (2007) to be $\sim 1^{\circ} \mathrm{C}$ and $0.3 \mathrm{~mm} \mathrm{~d}^{-1}$. The large difference between ob- 

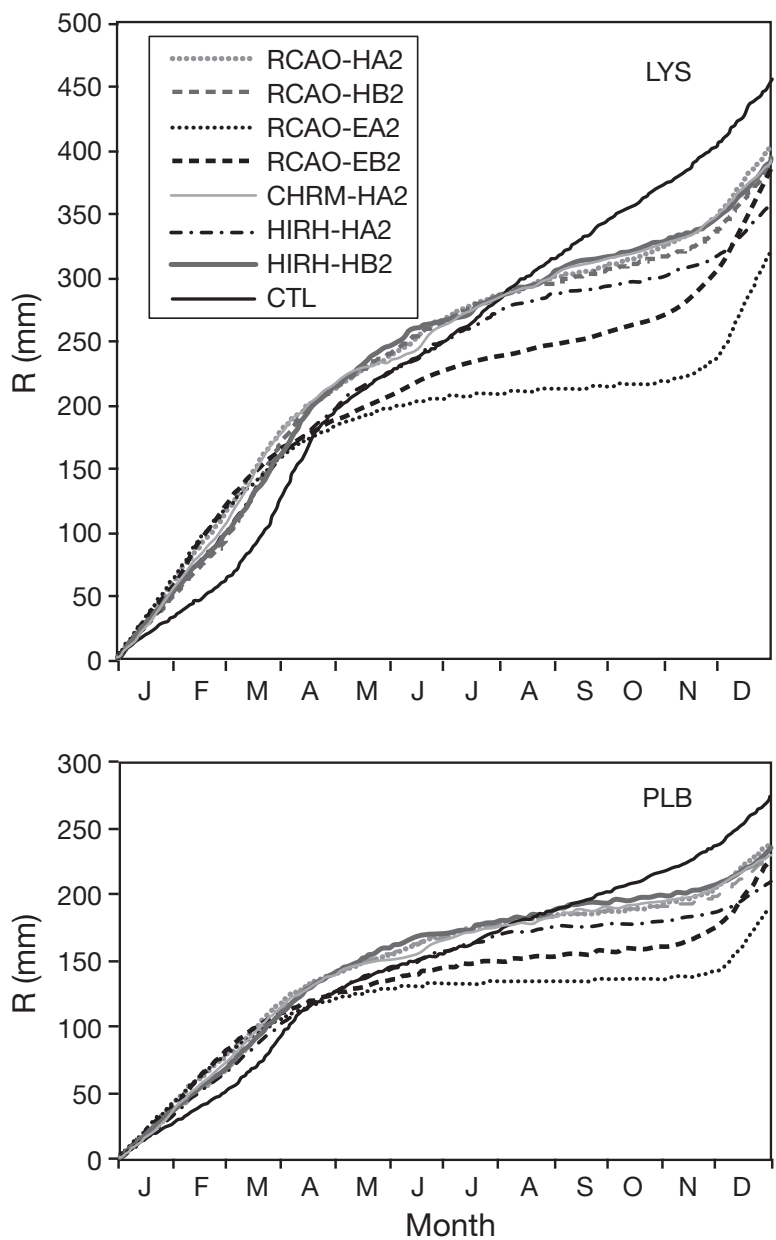

Fig. 10. Cumulative frequency distribution of mean daily runoff (R) for the control and scenario periods at the Lysina and Pluhův Bor catchments. See Section 2.5 for abbreviations

served and RCM-simulated radiation data (Fig. 4) might be attributed to the calculation method. Although Trnka et al. (2005) proved that the global radiation results using the method of Klabzuba were satisfactory for the growing season in central European conditions (with a relative mean bias error of $<10 \%$ ) (Trnka et al. 2005), this approach seems to underestimate the daily global radiation in our case. The difference between observed and RCM-simulated global radiation is the main reason for such remarkable runoff underestimation when using the uncorrected RCM data for Brook90 simulations in the control period (Fig. 5). However, when the parameters were set during the calibration period to the relatively lower radiation, the model validation was successful; thus, we assume that a systematic shift in bias corrected radiation should not affect the future runoff simulations.

The importance of bias correction in order to obtain realistic runoff series from the hydrological modelling was already suggested in the studies of Wilby et al. (2000), Fowler \& Kilsby (2007), Terink et al. (2010) and others. The method used here corrects only the mean monthly magnitude and does not correct the variability at the daily level (important for precipitation). This is resolved by more advanced bias correction methods such as 'quantile-mapping' used by Wood et al. (2004) and Schoof et al. (2009) or power law transform (Terink et al. 2010), which corrects for the coefficient of variation and mean of the precipitation value. However, Fowler \& Kilsby (2007) showed that the method based on a month-by-month correction provided only a small underestimation of variability, and they used it successfully for several relatively small catchments $\left(<50 \mathrm{~km}^{2}\right)$. Since the other above-mentioned studies were rather focused on large river basins (e.g. Rhine), the simple method was thus preferred.

The correction of RCM climatic data was slightly affected by the trend found in the measured data since this method normally assumes a stable climate. The trend found in the May maximum temperature shifted the average that was used to estimate the correction factor; thus, the difference between the RCM and the measured data were slightly lowered. However, trends found in the April maximum temperature and February precipitation amounts did not affect the correction since these were significant only in the period 1967-2006 and not in the period 19671990 that was used to estimate the error correction. This indicates that the trend is probably a result of changes from 1990-2006.

Based on the testing of parameter sensitivities and the parameter estimation process that provided optimal parameter sets with narrow CIs (Table 1), we believe that the model is robust enough to be used for estimating future changes in flow patterns at our investigated catchments. Nevertheless, the application of this local sensitivity approach could lead to misclassification of the sensitivities since it does not account for possible interactions among the parameters as noted by Tang et al. (2007).

The RCM model (driven by either HadAM3H or ECHAM4/OPYC3) with future scenarios (2071-2100; SRES A2, B2) estimates a wide range of winter precipitation increases ( 7 to $50 \%$ ) and summer precipitation decreases (6 to 53\%). The significant longterm rising trend in observed February precipitation data could be a signal of the future changes in seasonal distribution expected by the RCM under the different scenarios (e.g. Christensen \& Christensen 2007). Despite remarkable changes in the seasonal distribution of precipitation amounts, future changes on an annual level are almost negligible (Table 2). 
Changes in the long-term seasonal distribution of evapotranspiration were mainly reflected in increases, with a maximum in July $(\sim 15$ to $25 \%)$ at Lysina and in May ( 15 to 30\%) at Pluhův Bor. Future evapotranspiration could be more limited at the lower elevation Pluhův Bor catchment, where evapotranspiration decreased by $20 \%$ in August based on the ECHAM4/OPYC3 A2 scenario. This decrease could be a result of actual evapotranspiration being limited by water availability. The relatively high evapotranspiration increases in March and April $(\sim 40 \%)$ at both catchments clearly indicate a shift at the beginning of the growing season. Changes in annual evapotranspiration were expected to be $\sim+20 \%$ at Lysina and $\sim+15 \%$ at Pluhův Bor. It is worth noting that the model does not account for land-use change, and possible changes in the vegetation cover, which would significantly affect evapotranspiration. Estimating these, however, is beyond the scope of this paper. In principle, changes due to forestry management such as large-scale harvesting are unlikely since the catchments are located within a protected landscape area, limiting anthropogenic influences.

Essential changes in the seasonal runoff cycle represented by decreases in summer and increases in winter are more or less consistent with those of other studies using RCM outputs (e.g. Fowler \& Kilsby 2007, Graham et al. 2007, Driessen et al. 2010, Hurkmans et al. 2010). Increases in mean monthly runoff by $\sim+50 \%$ (LYS) and $\sim+30 \%$ (PLB) in winter were expected. However, the largest changes in future runoff were projected for summer and autumn, with reductions of 30 to $90 \%$ at Lysina and 30 to $95 \%$ at Pluhův Bor. On the other hand, the increase in June runoff (Fig. 9) resulting from the precipitation increase expected for June (based on the RCAO - HadAM3 modelling; Fig. 7) confirms that runoff would be more sensitive to changes in the seasonality of precipitation, especially in very small catchments. Significant decreases in spring runoff were also expected at both catchments. This clearly indicates shifts in snow melt and spring runoff maxima (Fig. 9), which is in accordance with published studies (e.g. Shabalova et al. 2003, Horton et al. 2006). Since spring and autumn are crucial periods for recharge, these reductions could be important for water resources or ecological management in the future. Changes in daily mean flow were even more substantial, especially in the late summer and autumn months. Estimations of future daily mean flow using corrected RCAO - ECHAM4/ OPYC3 A2 simulations showed a more severe de- crease in runoff compared to other RCM simulations (Fig. 10). Average decreases in mean daily runoff of 20 to $90 \%$ at Lysina and 25 to $95 \%$ at Pluhův Bor from August to November would be drastic changes, with consequences for catchment scale ecology and water management downstream. Changes in annual runoff were expected to be $\sim-20 \%$ at both catchments.

Uncertainties in our study are associated with different sources including emission scenarios, driving GCMs, downscaling by the RCMs, correction of the RCM outputs, and finally the uncertainty caused by the hydrological model. Selection of the GCM providing boundary conditions for the process of downscaling has a larger impact on the projected hydrological change than either the selection of emission scenarios or the RCM used for downscaling (Graham et al. 2007). Déqué et al. (2007) defined the uncertainty associated with using RCM data with the variance decomposition method. The method shows the role of different uncertainty sources (in uncertainty as a whole) as a percentage of the total variance explained by each source in the decomposition of temperature $(\mathrm{T})$ and precipitation $(\mathrm{P})$ variance. The results for middle Europe showed that the uncertainty due to the GCM is the largest, with 60\% uncertainty for both $\mathrm{T}$ and $\mathrm{P}$. This is followed by the uncertainty attributed to a scenario $(\sim 30 \%$ for $\mathrm{T}$ and $\sim 20 \%$ for P) and uncertainty due to selection of an RCM ( $\sim 20 \%$ for $\mathrm{T})$ and $\sim 30 \%$ for P). In our case, the sum of the percentages of uncertainty was $>100$ because of interaction terms. We assume that the range of error in the future runoff projections will remain similar to the error range estimated for the control period (Fig. 5). For the investigated catchments, the local scale bias correction of the RCM climatic data, followed by the selection of the GCM, had the most impact on changes to the hydrological patterns (Fig. 10).

\section{CONCLUSIONS}

Our results describe the impact of 7 plausible scenarios of climate change on 2 small catchments in the Slavkov Forest area for the period 2071-2100. We confirmed the need for correction of all climatic variables from the RCM model in order to characterize site specific conditions. Long-term annual series of mean runoff simulated with corrected RCM inputs and observed climatic data showed a similar pattern at both catchments in the control period (1967-1990). 
The estimated increase in temperature, and the seasonal redistribution of precipitation with expected summer decreases and winter increases, will significantly affect evapotranspiration rates and runoff in the future period 2071-2100. Evapotranspiration is expected to increase as a result of higher temperature and prolongation of the growing season. The annual runoff is projected to decrease and the annual cycle will change significantly. Winter runoff is expected to increase, runoff maxima will shift, and runoff in summer and autumn will decrease noticeably. The projected declines in mean daily flows indicate that the studied streams might regularly dry up for short periods in the summer and autumn. Similar scenarios can also be expected at other small size catchments in the Czech Republic.

Acknowledgements. Climate data were obtained through the PRUDENCE data archive (EU contract EVK2-CT2001-00132). A.B. was supported by the Norway and the European Economic Area Financial Mechanism (CZ 0051). The most recent research was supported by grants from the Czech Ministry of Environment (VaV SP/1a6/151/07) and the Norway and the European Economic Area Financial Mechanisms (CZ 0051) and the Operational Programme of European Union (CZ.1.05/ 1.1.00/02.0073). We thank 3 anonymous reviewers whose comments helped to improve this manuscript.

\section{LITERATURE CITED}

Christensen JH, Christensen OB (2007) A summary of the PRUDENCE model projections of changes in European climate by the end of this century. Clim Change 81:7-30

Christensen JH, Boberg F, Christensen OB, Lucas-Picher P (2008) On the need for bias correction of regional climate change projections of temperature and precipitation. Geophys Res Lett 35:L20709 doi:10.1029/2008GL035694

Clapp RB, Hornberger GM (1978) Empirical equations for some soil hydraulic properties. Water Resour Res 14: 601-604

Crawley MJ (2002) Statistical computing. An introduction to data analysis using S-Plus. John Wiley, Chichester

Cutter SL, Renwick WH (2003) Exploitation, conservation, preservation: a geographic perspective on natural resource use, 4th edn. John Wiley, New York, NY

> Déqué M, Rowell DL, Giorgi F, Christensen JH and others (2007) An intercomparison of regional climate simulations for Europe: assessing uncertainties in model projections. Clim Change 81:53-70

> Doherty J (2003) Groundwater model calibration using pilot points and regularization. Ground Water 41:170-177

Doherty J (2004) PEST: Model Independent Parameter Estimation user manual, 5th edn. Watermark Numerical Computing, Brisbane

> Driessen TLA, Hurkmans RTWL, Terink W, Hazenberg P, Torfs PJJF, Uijlenhoet R (2010) The hydrological response of the Ourthe catchment to climate change as modelled by the HBV model. Hydrol Earth Syst Sci 14:651-665

> Durman CF, Gregory JM, Hassell DC, Jones RG, Murphy JM
(2001) A comparison of extreme European daily precipitation simulated by a global and a regional climate model for present and future climates. Q J R Meteorol Soc 127: 1005-1015

> Federer CA (2002) BROOK90: a simulation model for evaporation, soil water, and streamflow. Available at http://home. roadrunner.com/ stfederer/brook/brook90.htm. Accessed 29 August 2010

Federer CA, Vörösmarty C, Fekete B (2003) Sensitivity of annual evaporation to soil and root properties in two models of contrasting complexity. J Hydrometeorol 4: 1276-1290

Fowler HJ, Kilsby CG (2007) Using regional climate model data to simulate historical and future river flows in northwest England. Clim Change 80:337-367

Frei C, Christensen JH, Déqué M, Jacob D, Jones RG, Vidale PL (2003) Daily precipitation statistics in regional climate models: evaluation and intercomparison for the European Alps. J Geophys Res 108(D3):4124. doi:10.1029/2002JD 002287

Graham LP, Hagemann S, Jaun S, Beniston M (2007) On interpreting hydrological change from regional climate models. Clim Change 81:97-122

Hanssen-Bauer I, Førland EJ, Haugen JE, Tveito OE (2003) Temperature and precipitation scenarios for Norway: comparison of results from dynamical and empirical downscaling. Clim Res 25:15-27

> Hewitt CD, Griggs DJ (2004) Ensembles-based predictions of climate changes and their impacts. EOS Trans Am Geophys Union 85:566

Horáček S, Kašpárek L, Novický O (2008) Estimation of climate change impact on water resources by using Bilan water balance model. IOP Conf. Series: Earth Environ Sci 4:012023 doi:10.1088/1755-1307/4/1/012023

> Horton P, Schaefli B, Mezghani A, Hingray B, André M (2006) Assessment of climate change impacts on alpine discharge regimes with climate model uncertainty. Hydrol Process 20:2091-2109

Hruška J, Krám P (2003) Modelling long-term changes in stream water and soil chemistry in catchments with contrasting vulnerability to acidification (Lysina and Pluhův Bor, Czech Republic). Hydrol Earth Syst Sci 7:525-539

> Hurkmans R, Terink W, Uijlenhoet R, Torfs P, Jacob D, Troch $P$ (2010) Changes in streamflow dynamics in the Rhine basin under three high-resolution regional climate scenarios. J Clim 23:679-699

Jasper K, Calanca P, Gyalistras D, Fuhrer J (2004) Differential impacts of climate change on the hydrology of two alpine river basins. Clim Res 26:113-129

> Krám P, Hruška J, Wenner BS, Driscoll CT, Johnson CE (1997) The biogeochemistry of basic cations in two forest catchments with contrasting lithology in the Czech Republic. Biogeochemistry 37:173-202

Levenberg K (1944) A method for the solution of certain nonlinear problems in least squares. Q Appl Math 2:164-168

Linsley RK (1949) Applied hydrology. McGraw-Hill, New York

> Marquardt DW (1963) An algorithm for least-squares estimation of nonlinear parameters. SIAM J Appl Math 11: 431-441

$>$ Nash JE, Sutcliffe JV (1970) River flow forecasting through conceptual models. 1. A discussion of principles. J Hydrol (Amst) 10:282-290

Nakićenović N, Alcamo J, Davis G, de Vries B and others (2000) IPCC special report on emissions scenarios. Cambridge University Press, Cambridge 
Oulehle F, McDowell WH, Aitkenhead-Peterson JA, Krám P and others (2008) Long-term trends in stream nitrate concentrations and losses across watersheds undergoing recovery from acidification in the Czech Republic. Ecosystems 11:410-425

Prudhomme C, Davies H (2008) Assessing uncertainties in climate change impact analyses on the river flow regimes in the UK. 1. Baseline climate. Clim Change 93:177-195

Räisänen J, Hansson U, Ullersteig A, Döscher R and others (2003) GCM driven simulations of recent and future climate with the Rossby Centre coupled atmosphere - Baltic Sea regional climate model RCAO. Rep Meteorol Climatol 101. Swedish Meteorological and Hydrological Institute, Norrköping

Schoof JT, Shin DW, Cocke S, LaRow TE, Lim YK, O'Brien JJ (2009) Dynamically and statistically downscaled seasonal temperature and precipitation hindcast ensembles for the southeastern USA. Int J Climatol 29:243-257

Shabalova MV, van Deursen WPA, Buishand TA (2003) Assessing future discharge of the river Rhine using regional climate model integrations and a hydrological model. Clim Res 23:233-246

Shuttleworth WJ, Wallace JS (1985) Evaporation from sparse crops - an energy combination theory. Q J R Meteorol Soc 111:839-855

Tang Y, Reed P, Wagener T, van Werkhoven K (2007) Comparing sensitivity analysis methods to advance lumped watershed model identification and evaluation. Hydrol Earth Syst Sci 11:793-817

Terink W, Hurkmans RTWL, Torfs PJJF, Uijlenhoet R (2010) Evaluation of a bias correction method applied to downscaled precipitation and temperature reanalysis data for the Rhine basin. Hydrol Earth Syst Sci 14:687-703

Trnka M, Žalud Z, Eitzinger J, Dubrovský M (2005) Global radiation in Central European lowlands estimated by various empirical formulae. Agric For Meteorol 131: 54-76

Vidale PL, Lüthi D, Frei C, Seneviratne S, Schär C (2003) Predictability and uncertainty in a regional climate model. J Geophys Res 108(D18):4586. doi:10.1029/2002JD002810

Wilby RL, Hay LE, Gutowski WJ, Arritt RW and others (2000) Hydrological responses to dynamically and statistically downscaled climate model output. Geophys Res Lett 27: 1199-1202

> Wood AW, Leung LR, Sridhar V, Lettenmaier DP (2004) Hydrologic implications of dynamical and statistical approaches to downscaling climate model outputs. Clim Change 62:189-216

> Yue S, Pilon P, Phinney B, Cavadias G (2002a) The influence of autocorrelation on the ability to detect trend in hydrological series. Hydrol Process 16:1807-1829

> Yue S, Pilon P, Cavadias G (2002b) Power of the MannKendall and Spearman's rho tests for detecting monotonic trends in hydrological series. J Hydrol (Amst) 259:254-271

Appendix 1. Monthly mean evapotranspiration (mm) for the Lysina catchment in the control (LYSCTL, 1967-1990) and scenario (2071-2100) periods (see Section 2.5 for abbreviations)

\begin{tabular}{|c|c|c|c|c|c|c|c|c|}
\hline Evap. & LYSCTL & RCAO-HA2 & RCAO-HB2 & RCAO-EA2 & RCAO-EB2 & CHRM-HA2 & HIRH-HA2 & HIRH-HB2 \\
\hline Jan & 9 & 12 & 11 & 13 & 12 & 12 & 11 & 11 \\
\hline Feb & 10 & 13 & 12 & 16 & 16 & 12 & 12 & 12 \\
\hline Mar & 15 & 22 & 20 & 27 & 25 & 20 & 21 & 19 \\
\hline Apr & 24 & 32 & 30 & 39 & 34 & 33 & 31 & 29 \\
\hline May & 49 & 59 & 56 & 63 & 59 & 60 & 60 & 58 \\
\hline Jun & 64 & 73 & 72 & 79 & 75 & 69 & 70 & 70 \\
\hline Jul & 64 & 79 & 75 & 73 & 74 & 74 & 77 & 75 \\
\hline Aug & 60 & 64 & 68 & 58 & 70 & 65 & 64 & 67 \\
\hline Sep & 41 & 43 & 46 & 45 & 50 & 48 & 46 & 47 \\
\hline Oct & 28 & 35 & 31 & 39 & 37 & 34 & 33 & 31 \\
\hline Nov & 14 & 17 & 17 & 21 & 21 & 16 & 15 & 16 \\
\hline Dec & 12 & 17 & 17 & 21 & 19 & 15 & 16 & 17 \\
\hline Year & 390 & 467 & 455 & 493 & 493 & 457 & 457 & 452 \\
\hline
\end{tabular}


Appendix 2. Monthly mean evapotranspiration (mm) for the Pluhův Bor catchment in the control (PLBCTL; 1967-1990) and scenario (2071-2100) periods (see Section 2.5 for abbreviations)

\begin{tabular}{|c|c|c|c|c|c|c|c|c|}
\hline Evap. & PLB CTL & RCAO-HA2 & RCAO-HB2 & RCAO-EA2 & RCAO-EB2 & CHRM-HA2 & HIRH-HA2 & HIRH-HB2 \\
\hline Jan & 9 & 12 & 10 & 12 & 12 & 11 & 11 & 10 \\
\hline Feb & 9 & 12 & 12 & 15 & 16 & 11 & 12 & 11 \\
\hline Mar & 16 & 22 & 20 & 27 & 25 & 21 & 21 & 19 \\
\hline Apr & 25 & 33 & 31 & 39 & 35 & 33 & 32 & 30 \\
\hline May & 50 & 60 & 58 & 64 & 60 & 61 & 62 & 59 \\
\hline Jun & 65 & 75 & 73 & 80 & 76 & 70 & 71 & 71 \\
\hline Jul & 67 & 81 & 78 & 72 & 76 & 77 & 81 & 78 \\
\hline Aug & 65 & 64 & 69 & 53 & 71 & 66 & 63 & 67 \\
\hline Sep & 45 & 45 & 46 & 45 & 51 & 50 & 47 & 48 \\
\hline Oct & 28 & 35 & 30 & 38 & 37 & 34 & 32 & 30 \\
\hline Nov & 14 & 16 & 15 & 19 & 20 & 15 & 14 & 15 \\
\hline Dec & 10 & 14 & 14 & 17 & 16 & 12 & 13 & 14 \\
\hline Year & 403 & 470 & 457 & 481 & 493 & 462 & 458 & 453 \\
\hline
\end{tabular}

Appendix 3. Monthly mean runoff (mm) for the Lysina catchment in the control (LYSCTL, 1967-1990) and scenario (2071-2100) periods (see Section 2.5 for abbreviations)

\begin{tabular}{|c|c|c|c|c|c|c|c|c|}
\hline Runoff & LYSCTL & RCAO- HA2 & RCAO-HB2 & RCAO-EA2 & RCAO-EB2 & CHRM-HA2 & HIRH-HA2 & HIRH-HB2 \\
\hline Jan & 34 & 60 & 48 & 62 & 56 & 54 & 52 & 52 \\
\hline Feb & 28 & 52 & 42 & 53 & 60 & 48 & 46 & 42 \\
\hline Mar & 61 & 65 & 75 & 43 & 47 & 72 & 58 & 64 \\
\hline Apr & 71 & 35 & 46 & 24 & 24 & 39 & 39 & 54 \\
\hline May & 33 & 26 & 28 & 15 & 20 & 20 & 29 & 34 \\
\hline Jun & 22 & 30 & 24 & 8 & 20 & 27 & 26 & 20 \\
\hline Jul & 33 & 19 & 21 & 4 & 12 & 22 & 23 & 19 \\
\hline Aug & 33 & 15 & 11 & 3 & 9 & 16 & 14 & 19 \\
\hline Sep & 30 & 9 & 10 & 3 & 10 & 16 & 6 & 13 \\
\hline Oct & 28 & 14 & 10 & 3 & 12 & 11 & 8 & 12 \\
\hline Nov & 31 & 24 & 19 & 18 & 35 & 21 & 15 & 17 \\
\hline Dec & 49 & 55 & 51 & 84 & 80 & 43 & 42 & 46 \\
\hline Year & 453 & 402 & 387 & 320 & 385 & 391 & 359 & 392 \\
\hline
\end{tabular}

Appendix 4. Monthly mean runoff $(\mathrm{mm})$ for the Pluhův Bor catchment in the control (PLBCTL; 1967-1990) and scenario (2071-2100) periods (see Section 2.5 for abbreviations)

\begin{tabular}{|c|c|c|c|c|c|c|c|c|}
\hline Runoff & PLBCTL & RCAO- HA2 & RCAO-HB2 & RCAO-EA2 & RCAO-EB2 & CHRM-HA2 & HIRH-HA2 & HIRH-HB2 \\
\hline Jan. & 28 & 42 & 34 & 42 & 40 & 37 & 35 & 37 \\
\hline Feb. & 23 & 35 & 31 & 36 & 39 & 35 & 31 & 30 \\
\hline Mar. & 41 & 41 & 47 & 28 & 30 & 42 & 36 & 41 \\
\hline Apr. & 34 & 22 & 26 & 15 & 15 & 25 & 25 & 31 \\
\hline May & 18 & 15 & 16 & 8 & 11 & 12 & 17 & 20 \\
\hline Jun. & 11 & 15 & 12 & 4 & 10 & 14 & 14 & 10 \\
\hline Jul. & 17 & 9 & 10 & 1 & 5 & 11 & 12 & 9 \\
\hline Aug. & 16 & 6 & 6 & 1 & 4 & 7 & 6 & 7 \\
\hline Sep. & 14 & 3 & 5 & 1 & 3 & 8 & 2 & 7 \\
\hline Oct. & 15 & 6 & 3 & 1 & 3 & 5 & 3 & 5 \\
\hline Nov. & 19 & 12 & 7 & 5 & 14 & 9 & 7 & 8 \\
\hline Dec. & 35 & 34 & 31 & 47 & 51 & 25 & 22 & 26 \\
\hline Year & 272 & 237 & 229 & 188 & 225 & 230 & 210 & 233 \\
\hline
\end{tabular}

Editorial responsibility: Tim Sparks, Cambridge, UK
Submitted: September 6, 2010; Accepted: May 2, 2011

Proofs received from author(s): August 24, 2011 